Rev. ANPOLL, n. 8, p. 131-166, jan./jun. 2000

\title{
ONDE CANTA O SABIÁ ${ }^{1}$
}

Marcos Falchero Falleiros

\begin{abstract}
RESUMO: José de Alencar e Graciliano Ramos apresentam diferentes concepçōes do Brasil. José de Alencar busca a empiria impossivel e Graciliano Ramos vê o pais no lugar do marxismo.
\end{abstract}

PALAVRAS-CHAVE: José de Alencar; Graciliano Ramos; colonialismo; marxismo; formas brasileiras.

$\mathbf{E}$ stremadas por quase um século, as obras de José de Alencar e de Graciliano Ramos encontram-se unidas pela intençāo de formular um quadro da nacionalidade, cujas concepçōes de mundo, entretanto, têm sua diferenciaçāo aguda determinada pela distância de tempo entre elas. Em Alencar, no momento da Independência e de uma literatura empenhada na sua própria configuração como valor e expressão nacionais, a busca de uma empiria impossivel debate-se exaustivamente com o mal-estar de quem quer colher, a qualquer hora da história e em qualquer lugar de seu território, as particularidades brasileiras, condicionado, entretanto, à importação

- Universidade Federal do Rio Grande do Norte-UFRN.

I Este ensaio, conclusivo da 1" fase - 1997-1998: Josė de Alencar e Graciliano Ramos - do projeto de pesquisa permanente Formas brasileiras, contou com o trabalho de Ector Pablo Dantas Beserra, bolsista de iniciaçāo cientifica pelo PIBIC, graduando em Letras pela UFRN nesse periodo. Além disso, o ensaio retoma momentos de minha dissertação de mestrado sobre Graciliano Ramos. A retórica do seco (USP, 1990) e de minha tese de doutorado Ingenuidade e brasileirismo em Manuel Bandeira (USP, 1995). 
FALLEIROS, Marcos Falchero. Onde canta o sabiá.

do romance e aos padrões europeus de sua origem colonial. Em outro tempo, Graciliano Ramos tenta construir sua obra no lugar do marxismo, o que faz de seu regionalismo mero álibi para provar as possibilidades históricas do país e examinar suas circunstâncias sob a perspectiva universalista do materialismo dialético. Antonio Candido contrapõe à jocosidade fluida de Memórias de um sargento de milicias, a literatura cristalizada de Alencar, representante de projetos de elite. Entretanto é necessário lembrar que a obra severa de Graciliano Ramos relativiza essa distinção ao mostrar que a vertente cristalizada pode estar expressando, sob causa popular, uma vontade de ordem como vontade de justiça, atravês da qual um mapeamento marxista das condições históricas brasileiras é o que dirige a articulação de seus romances, com sua temática ficcional se esgotando com precisão nas três classes sociais, sob o mosaico do estilo seco e econômico, à feição da terra que se contrai em rachaduras.

\section{Dois mapas do Brasil:}

\section{Graciliano Ramos e José de Alencar}

No prefácio a $O$ caráter nacional brasileiro de Dante Moreira Leite, sob o título "Aventuras e desventuras de uma ideologia". Alfredo Bosi pergunta sobre a possibilidade teórica de qualificar um caráter "nacional" e, no caso, "brasileiro": "Em que a empiria pode ser resgatada?". Num ensaio posterior, Céu, inferno (1988), inicia a análise de Vidas Secas assim: "Sem dúvida, o capital não tem pátria, e esta é uma de suas vantagens universais que o fazem tão ativo e irradiante. Mas o trabalho que ele explora tem mãe, tem pai, tem mulher e filhos, tem lingua e costumes, tem música e religiāo". Em outro momento, situado num Brasil mal-saido de um regime militar que funcionou como instrumento de consolidação e expansão do capitalismo internacional, entende que tais particularidades ilham-se num espaço menor que o da nacionalidade, argumentando, entretanto, que o con- 
trário do não-caótico è o plural (1987): com a forma pretérita do "já houve quem", em referência às tentativas de caracterizar a cultura brasileira como unitária e coesa, observa que se procurava defini-la cabalmente com um adjetivo, e que, vinculados a essa "qualidade mestra", existiam interesses de afirmar uma unidade nacional. Para dar continuidade à superação critica dessa idéia de uma cultura brasileira homogênea, "matriz dos comportamentos e discursos", propōe o seu caráter plural, por onde se tornaria possivel a abordagem de um processo cuja compreensão como um "efeito de sentido" passa pelo entendimento de suas múltiplas interações históricas e dialéticas.

Se essa demarcação do problema desencoraja a qualificação de uma particularidade una, que exprimiria a essência do adjetivo "brasileiro", serve também para mostrar como é mais fácil à precariedade da doxa, condição humana da teoria, aluir o denominador comum das pluralidades.

Assim, o Alfredo Bosi de 80 irmana-se ao Dante Moreira Leite de 60, que se irmana ao Caio Prado Júnior de 1940 - que é quem ao fim da linha aparece como o deflagrador do momento decisivo em que a história ideológica do pais desaclimata a tendência culturalista da particularidade una, por uma abordagem econômica marxista, universalismo ilustrado em movimento de uniāo antitética à racionalidade do capital imperialista. Generalização e razão são conceitos próximos e o adjetivo tautológico e paradoxalmente metafisico do "homem humano" é a ponte, em nome do substantivo das classes oprimidas, sobre o rio da particularidade pouco definivel do "brasileiro". Com essa epigrafe trazida de Guimarāes Rosa, Dante Moreira Leite abre sua obra, que historia o antigo debate e o anula apresentando a intervençāo de Formaçāo do Brasil contemporâneo, de Caio Prado Júnior: a novidade critica patenteava-se fundamentalmente na superação da particularidade regional, ponto de vista por onde, até então, a partir de um aspecto situado, procurava-se extrair o eixo sobre o qual girasse toda a História do Brasil. Caio Prado Júnior, pelo contrário, armou um esquema objetivo para apanhar as múltiplas ativi- 
FALLEIROS, Marcos Falchero. Onde canta o sabiá.

dades regionais em função de uma atividade básica: a colonização. A diferença se faz sentir no próprio modo de recepção dos documentos sobre a população desocupada da colônia, conforme destaca o exemplo de Dante Moreira Leite. Ao invés de preguiça, "decadência dos trópicos", "degeneração do híbrido", a interpretação pela visada econômica abandona a aderência conivente ao documental e desvenda, atrás do "dado", um sistema colonial praticamente sem possibilidade e oportunidade para o trabalho livre.

Antonio Candido no prefácio a Raizes do Brasil (1984: xiii) endossa a afirmativa e testemunha o impacto de novidade que no sentido acima mencionado o aparecimento da obra de Caio Prado Júnior causou frente ao que havia de beleza e expressividade de estilo, tanto na obra que prefacia quanto em Casa-grande \& senzala, ambas representativas de um "literário" espirito-do-tempo, que era então superado: "Nenhum romantismo, nenhuma disposiçāo de aceitar categorias banhadas em certa aura qualitativa - como 'feudalismo' ou 'familia patriarcal' - mas o desnudamento operoso dos substratos materiais. Em conseqüência, uma exposição de tipo factual, inteiramente afastada do ensaismo (marcante nos dois anteriores) e visando a convencer pela massa do dado e do argumento".

Entretanto, se o marco de publicação da obra são os anos 40 é de convir que a década anterior já a preparava, como se vê na crônica de Graciliano Ramos sobre aquele periodo, intitulada "Bagunça", dando, bem ao seu estilo, o sentimento de instabilidade ideológica e político-social que a virada do novo tempo trazia com a Revolução de 30 e os diversos tipos de mobilização que implicou. $O$ elemento pedestre e despachado do título tira um pouco o ar de camarote com que Graciliano Ramos aprecia a movimentação. No entanto, a crônica, rememorativa, datada de agosto de 1941, é de alguém que freqüentava o Palácio do Governo em Maceió, como diretor da Imprensa Oficial, era chegado ao governador e esteve preso por uma noite, acusado, sob ameaças de fuzilamento, de ter conspirado e de ter escrito o texto de um panfleto que fora distribuido por aviāo e cuja finalidade era 
apaziguar e desmobilizar a população com desmentidos sobre a movimentação revolucionária. Própria ao estilo do autor e ao contexto universalizante - marxista - de que proveio, a tendência ao plural generalizante fixa os fatos no âmbito convicto do "é assim que é", e o retrato assimila e expressa, sem deixar se levar por ele, o movimento de transformaçāo que descreve: "A maioria animava-se de verdade, oferecia moedas de prata para a liquidaçāo da divida externa, esperava que altos-fornos se construissem de repente, corresse o petróleo e a população subisse a duzentos milhões. Esses desejos encurtaramse, mas ainda ficaram extensos, e moços verbosos, falando muito na realidade brasileira, procuraram em paises distantes receitas convenientes aos males nacionais. Os politicos maduros, educados na poesia e na retórica, arrepiavam-se ouvindo sujeitos imberbes que se agarravam à economia e à sociologia, citavam livros desconhecidos.

- Que materialismo!" (1976: 61).

E o momento caracterizado por Antonio Candido como o da "alteração marcada de perspectivas", que reverte a visão ufanista do "país novo" para a noção depressiva de "pais subdesenvolvido": "desde o decênio de 1930 tinha havido mudança de orientação, sobretudo na ficção regionalista, que pode ser tomada como termômetro, dadas a sua generalidade e persistência. Ele abandona, então, a amenidade e curiosidade, pressentindo ou percebendo o que havia de mascaramento no encanto pitoresco, ou no cavalheirismo ornamental. com que antes se abordava o homem rústico. Não é falso dizer que, sob este aspecto, o romance adquiriu uma força desmistificadora que precede a tomada de consciência dos economistas e politicos" (1987: 142).

Em relaçāo a esse periodo é interessante observar que Afrânio Coutinho, ao caracterizá-lo como o momento de alcance da maturidade da consciència literária brasileira, utiliza como testemunho o depoimento de Gilberto Freyre, que, como foi visto, estava no plano teórico preso a um tipo de ensaismo literário que era entāo superado pela objetividade materialista de Caio Prado Júnior: "Foi durante a 
FALLEIROS, Marcos Falchero. Onde canta o sabiá.

década de 1920 e 1930 que a consciência literária brasileira atingiu a maioridade. Entāo perderam os brasileiros a noçāo de expatriamento cultural, podendo-se ai situar 'o nascimento do Brasil e o conseqüente esmorecer da Europa dentro de nós', como diz com justeza Gilberto Freyre (Minha formaçāo no Recife, p. 353-5), acrescentando palavras precisamente de 1926 que registram o fenômeno" (1968: 36).

Estendendo esse processo ao Romantismo, o curioso de tal passagem é que o registro da percepção de mudança é mencionado com o testemunho de um autor cujo estilo prolixo e o à-vontade das observações impressionistas pouco rigorosas revelam sua permanência de fato no mundo passado. O mesmo diapasão impede ao autor a diferenciaçāo entre o Romantismo e o Realismo de 30: "Naquela época [Romantismo], presos muito embora por laços culturais à Metrópole, já conquistáramos a consciência de nossa nova moldura física e social e a noção de que a literatura poderia produzir-se sob formas novas, exprimindo novos matizes de sensibilidade e uma nova experiência. Foi o movimento em que a velha psiquê colonial cedeu o lugar a forças espirituais que plasmavam, na alma do povo, uma nova mentalidade literária".

Mas de qualquer modo é significativa para os objetivos de nosso estudo a observação conseqüente: "O 'shock of recognition' dessa mudança encontra-se na polêmica em torno de $A$ confederação dos tamoios (1856), em que participaram José de Alencar, Araújo Porto Alegre, Monte Alverne, Alexandre Herculano, Castilho, Pinheiro Guimarães e o próprio D. Pedro Il. É o momento em que a consciência literária se corporifica, em que os problemas literários sāo encarados de maneira técnica, em que surge a consciência de que se estava fazendo literatura sob feitio novo". Atribuindo a Alencar o titulo de patriarca da literatura brasileira, dado o papel assumido pelo escritor na tarefa desse momento de transformação, o critico acrescenta: "Estudadas as suas cartas sobre a $A$ confederação dos tamoios (1856) e sua autobiografia literária Como e por que sou romancista (1873), bem como sua polêmica com José Feliciano de Castilho (1872), verifica-se 
a noção que ele tinha dos problemas literários, e das grandes obras representativas dos vários gêneros, reportando-se, na sua argumentação, às provas fornecidas pelos grandes autores. Ao lado do estudo das formas literárias, tinha ele bem presente no espirito o problema de como dar realização 'brasileira' à literatura, preocupação absorvente dos homens de letras de então, de conformidade com aquele 'instinto de nacionalidade', que caracterizava a época, como salientou mais tarde (1873) Machado de Assis".

A demarcação de intenções semelhantes dentro de um projeto de reconhecimento e identificaçāo da nacionalidade perde as diferenças dos tempos e o processo imanente de amadurecimento que o tema perfaz em seu desdobramento histórico, como também a peculiaridade de interpretaçāo e recepção por que passaram as obras de José de Alencar e de Graciliano Ramos, tendo em vista a concepção e projeto para o pais, em torno dos quais cada obra se articula.

Relativamente à obra de Alencar, tal temática é mais explicita por ter sido nāo só debatida pelo autor, mas também enfocada como um dos tópicos caracteristicos de sua fortuna critica, que não nega sua importância para a formação da literatura brasileira, mas polemiza o sentido que o autor quis dar a suas propostas. No prefácio a Sonhos $D^{\prime}$ Ouro, ali casualmente localizado em razāo do momento em que ocorria a polêmica com escritores e criticos lusófilos, para rebater os censores intolerantes com os "americanismos" de sua linguagem e com a irrealidade dos entrechos, Alencar explicita o projeto nacionalista de sua literatura, afirmando-o como um "projeto orgânico", que, àquela altura, já contava com três fases, assim comentadas por Alfredo Bosi em História concisa da Literatura Brasileira: a) a fase primitiva, chamada por Alencar "aborigene", seria aquela em que se recupera, para o estágio culto da literatura, as lendas, mitos e tradições da infância da nação, o indio: exemplo maior: Iracema; b) a fase histórica, em que o registro recai sobre o "consórcio" entre o povo invasor e a "terra americana": trata-se do periodo colonial de O Guarani e As Minas de Prata, fase que se encerra com a Independência, dando lu- 
FALLEIROS, Marcos Falchero. Onde canta o sabiá.

gar ao seu efeito; c) a "infância de nossa literatura" que, balbuciante, espera escritores que procurem o "sainete todo brasileiro", onde ainda não se propaga a luz da civilização.

Descontado o momento da polêmica, com suas conseqüências posteriores, que levantam debate entre o apriorismo "programático" e a casualidade das escolhas temáticas de Alencar, confirma-se ai, de qualquer modo, a consciência do papel histórico que o escritor tinha em relação à sua obra. É o que fortalece a concepçāo de Antonio Candido sobre a formação da literatura brasileira ter ocorrido no contexto de uma arte "interessada", no sentido extemporâneo do termo, que designa um "engajamento" com o significado lato de interesse e empenho pela formação cultural de uma nacionalidade.

É sob esse sentido que há, em Graciliano Ramos, de um modo até agora inapreendido pela crítica, um projeto implícito em sua obra, cuja conceptualização marxista, ainda que independente de diretrizes partidárias, examina a partir do Nordeste as circunstâncias históricas do Brasil e perscruta as perspectivas que ela oferece. Nesse caso, claramente, não hả um apriorismo programático, mas o percurso de uma obra que, por conseqüência lógica e coerência ideológica de suas angustiadas indagaçōes, chega a um mapeamento da realidade histórica que representa, armada como uma grade de conjunturas onde a subjetividade se encontra presa.

É que, nesse caso, o escritor "teórico" pôde, efetivamente, vivenciar o momento histórico da "sociologia" e, assim, com sua literatura a seco e a grandeza artística de não transformá-la em romance de tese, construir um projeto histórico para o pais a partir do seu âmbito nordestino e subjetivo. Longe, entretanto, do nacionalismo ingênuo que permeou a história recente da Independência, Graciliano viveu o momento de maturação que lhe permitiu elaborar esteticamente aquele projeto na direção universal das classes sociais. Sem estereotipar as classes, as condiçōes e os individuos, sua literatura pôde criar tipos humanizados e situados concretamente na vida da divisão social, para alçançar o mapeameṇto das condiçōes de possi- 
bilidade da luta de classes: o burguês em São Bernardo, na Revolução de 30, o pequeno-burguês em Angústia, no Levante de 35, e a expectativa desolada, que perscruta o caminho aberto da História na dolorosa migração rumo à proletarizaçāo em Vidas Secas, no Estado Novo de 37.

\section{No lugar do marxismo}

A arrumação da história em Graciliano Ramos cruza a seca com o econômico e cria o estilo à semelhança da terra que se contrai em rachaduras. Nesses mosaicos de recortes escuros o processo econômico estereotipa os papéis exemplares e constrói os "símbolos" que sāo Fabiano e familia ou, por outra, os tipos "médios" - mas plenos como viu Carlos Nelson Coutinho: "Graciliano aproxima Fabiano mais do que qualquer outro de seus personagens realistas - do universal, da 'média'. Fabiano não realiza nenhuma das possibilidades extremas contidas em sua classe (por exemplo: a revolta consciente, a adesão ao cangaço, ao beatismo etc.); mas com isso, não perde a sua singularidade, a sua individualidade, ainda que não seja - como Paulo Honório, Madalena ou Luis da Silva - um tipo excepcional. Por isso, de modo algum ele é uma alegoria, uma encarnaçāo simbólica de principios abstratos", "Ao lado da exigência formal, estrutural, a própria realidade permitia essa caracterização: ela se baseia, sobretudo, na baixa complexidade da psicologia de nosso camponês, o que torna dificil e problemática, ainda que nāo impossivel, uma caracterizaçāo mais singularizada e individualizada. Mesmo como tipo médio - e, no caso, talvez precisamente por isto Fabiano é um tipo autêntico e realista, um tipo particular, ainda que voltado mais para a universalidade do que para a singularidade" (1967: 179).

A uniformidade sob prisma universalizante do econômico é o quadro do qual participa o autor, dando-lhe alta expressão estética em seu tempo, quando o espectador maduro de Linhas tortas, escre- 
FALLEIROS, Marcos Falchero. Onde canta o sabiá.

ve, miserável depois da cadeia, mal instalado na pensão da Rua Correia Dutra, no Rio de Janeiro, no Catete, as histórias dos "individuos parados" de Vidas secas, semelhantes aos que encontra numa peça teatral: "O cidadão fica na calçada, hesitante, um olho na sala de espera, outro na rua. Compra o bilhete, entra - e dão-lhe uma surpresa, uma peça sem enredo" - escreve com espanto. Nesse periodo o Estado Novo estava sendo decretado e pelo menos desde maio daquele ano Graciliano Ramos escrevia os capitulos de Vidas secas. Trata-se de uma crônica datada de novembro de 1937, sobre a peça $O$ rio: "uma coisa estranha no teatro brasileiro", "pedaços de história", "retalhos de vidas incongruentes", "nenhum tipo a mostrar-se demais", "Álvaro transforma-se em doido e Eugênia em prostituta, sem as gargalhadas clássicas e a canalhice, inevitáveis nos doidos e nas rameiras que ficam em tábuas. Sempre achei esquisitas essas gargalhadas e essa desfaçatez", "No fim um sujeito brada à mulher desgraçada: 'O nosso dia há de chegar' " (1980: 169).

No contexto do desinchaço das "gargalhadas" e da "desfaçatez" canastronas, aparece a linguagem generalizante do "ficam em tábuas", popular e próxima da psicologia da giria, agressiva com o estabelecido e desmistificadora, do mesmo modo como Graciliano distingue a cidade, no Rio de Janeiro, do morro. A primeira ele chama de "planicie": "Uma, duas vezes por semana, a cuica ronca no morro, onde se elabora a fornada nova de sambas que a cidade vai ouvir durante o carnaval. Essa elaboração, porém, não se faz toda nas casas de madeira e lata: começa aí, mas a segunda fase da produção realiza-se na planície. O morro vende matéria-prima e compra mercadoria - dá ritmos e sentimentos, recebe obras musicadas, literalizadas, impressas em folhetos, expostas no disco e no rádio" (1980: 215).

O traço popular, essencial à retórica do seco, nomeia palco e teatro com "tábuas", num misto de precariedade e grosseria de expressão com revolvimento da linguagem estabelecida, cujo caráter sinedóquico (a matéria pelo objeto, a parte pelo todo) é fraterno ao processo da giria: dela ele traz a desconfiança, a agressividade, a de- 
sapropriaçāo desautorizada e a ironia rotineira e irreverente revestindo as palavras e desestabilizando-as. Ao mencionar doidos e rameiras "que ficam em tábuas", torna-se ao mesmo tempo o estilo da percepçāo que vê o "homem rústico" longe tanto do "cavalheirismo ornamental", de que fala Antonio Candido, como das "gargalhadas" e da "desfaçatez".

O modo popular nos tempos modernos vem da mesma alienação que, se abrutalha a ingenuidade, no mesmo passo, entretanto, dessacraliza e simplifica sua relaçāo com o mundo. Tal estado depauperado nesse estágio aninha o chocar da democracia absoluta - esse pode ser o sentido mais profundo da palavra "despachado".

É moderno ir buscar as máscaras africanas primitivas não só porque lá estão as linhas retas da maquinaria burguesa. O desenho infantil também começa assim: a geometria é o menor caminho entre dois pontos. Marx disse: "todo começo é dificil". O estado de alienação do homem também é um zero inicial - e denso, porque a presença humana ainda está lá em sua raiz sugada. Ir às linhas retas é fraterno ao popular porque trata-se de um tempo inaugural que as máquinas ladras e opressoras da burguesia instauram. É a simplificação num tempo em que a morte da metafísica significa a percepçāo do direito humanista universal da ascensão popular à dignidade, sua prontidão inquieta assediando a história.

Ao falar sobre o alastramento em cadeia da maquinaria, na passagem da manufatura para a grande indústria, diz Marx sobre o rigor mecânico: "O quanto, no começo, a velha forma do meio de produçāo domina sua nova forma mostra-o entre outras coisas, [...] e talvez de modo mais convincente do que qualquer outro, uma locomotiva experimentada antes da invenção das locomotivas atuais e que tinha, de fato, duas patas que erguia alternadamente, como um cavalo. Só depois do ulterior desenvolvimento da mecânica e com a experiência prática acumulada é que a forma passa a ser inteiramente determinada pelo principio mecânico, e portanto totalmente emancipada da antiga forma corpórea tradicional da ferramenta, que se metamorfoseia 
em máquina". E: "Mas tratava-se também de produzir as formas rigorosamente geométricas necessárias às partes individuais da máquina, como linha, plano, circulo, cilindro, cone, esfera, de maneira mecanizada. [...] Esse dispositivo mecânico, que não substitui qualquer ferramenta particular mas a própria māo humana, produz uma forma determinada mediante aproximaçāo, ajustamento e orientaçāo do fio de instrumentos cortantes. [...] Conseguiu-se, assim, produzir as formas geométricas das partes componentes da máquina 'com um grau de facilidade, de precisão e rapidez que nenhuma experiência acumulada da mão do mais hábil trabalhador poderia conseguir' " (1983: 15-16).

"A razão é essencialmente construtora de máquinas"- diz Granger (1969: 120). Analisando as relaçōes entre arte e máquina, Pierre Francastel fala sobre o momento de euforia causado pela "apoteose da máquina" na Exposição de Paris em 1890: "Deslumbrados com os seus incontestáveis êxitos, vêem-se então os engenheiros arrogar-se, a seguir a Eiffel, o titulo de criadores de beleza. Mais exatamente: a palavra desaparece do vocabulário deles para ser substituida pela de utilidade. Identificando também a beleza como algo de definitivo, de imutável, os técnicos resolvem, por seu turno, fazer-se criadores duma outra forma de expressão em que se traduza o seu recente triunfo sobre a matéria". "Nessa altura, decorria a cruzada de Loos contra o ornato. Julgava-se ter encontrado no banimento da decoração de superficies a solução estética do problema da arte moderna. Substituir-se-ia a ornamentação, que é anedótica e exterior ao objeto, pela expressão declarada da funçāo preenchida. A alma da máquina tornar-se-ia aparente e traduziria a grandeza do novo esforço humano" (s.d.: 44-45).

A respeito da receita "ovo de Colombo" da poesia de Oswald de Andrade, Roberto Schwarz, em seu ensaio $A$ carroça, o bonde e o poeta modernista, relaciona sua "fórmula fácil e poeticamente eficaz de ver o Brasil" à tese critica, "segundo a qual o esoterismo que cercava as coisas do espirito era uma bruma obsoleta e antidemocrática, a 
dissipar, fraudulenta no fundo". Schwarz menciona ainda, de Lenin, a convicção de que o Estado revolucionado poderia ser administrado por uma cozinheira, e, de Brecht, menciona suas propostas de pensamento sem requinte, vocabulário reduzido e elaboração de protótipos artisticos. O "horizonte comum" em que os três homens podem ser vistos juntos é "ditado na época pela crise geral da ordem burguesa e pelas perspectivas abertas pelo progresso industrial" (1987: 12).

Paulo Honório, escrevendo São Bernardo, canaliza como personagem a concepçāo utilitária e pragmática que Graciliano Ramos tem da literatura. Graciliano está para o bacharelismo como Marx para a metafisica. Procura fazer literatura como engenheiro - modo a que João Cabral de Melo Neto deu curso explicito e estetizante posteriormente, como a apurar uma linha de expressão seca e nordestina, formando tronco, consciência e tradiçāo. A linguagem dos famosos relatórios de Graciliano quando prefeito de Palmeira dos Índios esclarece a relaçāo do estilo com a personagem, fazendo confluir na voz do burguês pragmático o sotaque autoritário do coronel, que enternecido vira literato. Por isso ao mesmo tempo tal representação configura uma vingança sobre o burguês vitorioso, significando simultaneamente a justificativa do fracasso do autor, literato: catarse simultânea do ornamental bacharelesco e da ideologia pequeno-burguesa do pragmático "hei-de-vencer", dialeticamente marxista.

Fora da cena, o texto se repete inversamente com Graciliano Ramos, que olha desoladamente para a literatura como com a sensação da falta de sentido com que Paulo Honório olha para a fazenda. Escrevendo à mulher, em abril de 1935, tempo de Angústia e véspera do levante comunista que o levaria à prisāo, diz: "O Estado está pegando fogo, o Brasil se esculhamba, o mundo vai para uma guerra dos mil diabos, muito pior que a de 1914 - e eu só penso nos romances que poderão sair dessa fornalha em que vamos entrar", "Por ai você vê que eu sou um monstro ou um idiota", "Mesmo os que são doentes, os degenerados que escrevem história fiada, nem sempre nos inspiram simpatia: é necessário que a doença que nos ataca atin- 
FALLEIROS, Marcos Falchero. Onde canta o sabiá.

ja outros com igual intensidade para que vejamos nele um irmāo e lhe mostremos as nossas chagas, isto é, os nossos manuscritos, as nossas misérias, que publicamos cauterizadas, alteradas em conformidade com a técnica".

Trata-se do mesmo gesto pragmático com que Marx, filosofando, dita a XI tese sobre Feuerbach: "Os filósofos se limitaram a interpretar o mundo de diferentes maneiras; o que importa é transformálo". Assim Graciliano transmite à mulher o seu sentimento de inutilidade: "É possivel que nos metamos novamente em Palmeira, que eu compre algodāo e venda trapos. Mas com certeza hei de comprar e vender muito mal. Comprando algodão ou vendendo fazenda, construindo o terrapleno da lagoa ou entregando os diplomas às normalistas (não vale a pena contar: fol uma estopada), hei de fazer sempre romances. Não dou para outra coisa. Ora aqui há uns dois ou três individuos que falam comigo. Aí não há nenhum. Estou, pois, com vontade de ir para Minas, onde há muitos leprosos" (1980: 143).

Como Marx, Graciliano relaciona interpretação a transformação - ao contrário do fascismo positivista, cujo empirismo factual Marcuse apresenta como traço marcante de sua finalidade: "A felicidade sob a proteção de um braço forte - atitude hoje tão caracteristica das sociedades fascistas - está ligada ao ideal positivista da evidência. A perfeita evidência de teoria e prática, afirma Comte, é uma das conquistas básicas do método positivista". Trata-se ai de opor "progresso" à "revolução": "A idéia de progresso, de Comte, exclui a revoluçāo, isto é, a total transformaçāo do sistema dado de circunstâncias. O desenvolvimento histórico tornava-se nada menos que a evolução harmoniosa da ordem sob leis 'naturais' perenes" (1978: 318).

A atitude pragmática, representando o fim da metafisica, unifica na modernidade a oposiçāo entre marxismo e positivismo. Razāo e revolução posicionam-se em luta contra os ditames da ordem para o progresso. A sensibilidade do desenraizado e a observaçāo do categórico são dinamizadas pela reflexão que seu racionalismo construtivo 
pratica com rigor ao ponderar a armaçāo de seus personagens e interrogar-se sobre a utilidade deles. "Devo declarar, logo no começo, que nunca supus ajeitar-me a este indecente meio de vida. É certo que, por volta dos treze anos, achei que devia ser agradável construir uma espécie de Inocència ou Casa de pensāo e fiz algumas tentativas" (1980: 194) - diz Graciliano em "Alguns tipos sem importância", um texto sobre seus personagens que ele se viu obrigado a escrever por encomenda de um amigo da imprensa.

Graciliano Ramos, porque passou um bom pedaço de sua vida atrás de um balcão, na Loja Sincera, resvala a figura caricata de um comerciante de cidadezinha do interior, como o farmacêutico Homais em Madame Bovary. O homem que mais sabia mitologia no sertão, como dele disse José Lins do Rego (1943: 89), era o "sábio" da cidade, mas nunca foi idiota como o personagem de Flaubert. A voz do autor, presente em qualquer texto de Graciliano Ramos, nos relatórios, nos artigos, nos discursos e nos romances, é sempre viril no caráter, mesmo que a modéstia venha a se tornar insistente. Este aspecto, antes de ser nódoa, vai dando o traço popular de sua afetação constrangida, a marca de um caráter altaneiro espantado com a importância que lhe é atribuida, seqüestrando-o do anonimato coletivo, apesar da situação pequeno-burguesa que em seu meio provinciano lhe dera condição de elite. É o que vemos em Homenagem a Graciliano Ramos, a respeito do jantar comemorativo de seus cinqüenta anos, com muito discurso e um cardápio em que os pratos eram batizados com os títulos de sua obra, entre outros salamaleques, numa situaçāo extremamente constrangedora para o seu caráter, como sentiu na ocasião Carlos Drummond de Andrade.

Categórica e modesta, firme e bruta, econômica e pobre, a retórica do seco dá expressão forte ao anti-bacharelismo que combateu na modernidade do século XX o alambicado da literatura brasileira. No depoimento sobre seus personagens, o autor encerra o parágrafo acima citado nestes termos: "Com o correr do tempo os modelos se tornaram maiores, mas ai veio o bom senso e vieram ocupaçōes razo- 
FALLEIROS, Marcos Falchero. Onde canta o sabiá.

áveis: a idéia de ser literato desapareceu completamente". Nessa nova perspectiva do "espirito do tempo", Graciliano é o irônico pragmático que apresenta a literatura como um vicio e o utilitário filosófico que questiona as intençōes da arte. Ele faz literatura para eliminá-la. Nesses tempos de "infra-estrutura", o literato rústico que utiliza pragmatismo e reflexão no fabrico da retórica do seco sabe que cada vez mais a inocência perdida dos homens se crispa na consciência de que é necessário fazer para comer.

João Luiz Lafetá equaciona o periodo abrindo-lhe as faces conjugadas do "projeto estético" e do "projeto ideológico". Depois da "fase heróica" de 22, bem-humorada e disponivel, a politização dos anos 30 faz com que o projeto ideológico se acentue - e a estética de Graciliano Ramos pode ser o exemplo mais forte disso: politização da forma. É tempo de discutir a "função da literatura, o papel do escritor, as ligaçōes da ideologia com a arte" e de retomar e aprofundar "a tradição que vem de Euclides da Cunha, passa por Lima Barreto, Graça Aranha, Monteiro Lobato: trata-se da denúncia do Brasil arcaico, regido por uma politica ineficaz e incompetente". Esta é, segundo Lafetá, a diferença entre os dois momentos do Modernismo brasileiro: "A ideologia de esquerda não encontra eco nas obras da 'fase heróica': se há denúncia das más condiçōes de vida do povo, não existe todavia consciência da possibilidade ou necessidade de uma revolução proletária" (1974: 17).

Mas o núcleo contraditório em que Graciliano Ramos se encontra é o horizonte fechado da estética stalinista, um disparate para quem pretende em sua arte alcançar o homem inteiro ("interior" e "exterior"), infenso à fachada artificializada dos heróis saltitantes do realismo socialista com seus olhos de escoteiro postos no infinito: "No decurso da história literária, a reprodução naturalista do real tomou formas muito variadas. Aquilo que a caracteriza sempre é o enfraquecimento ou a perda total desta mediaçāo concreta e evidente entre os fatos individuais e os principios ligados a concepçōes do mundo. Pode dizer-se, neste sentido, que o praticismo e o empirismo 
correspondem a uma concepção do mundo muito próxima daquela que, em literatura, está implícita no naturalismo" - eis a avaliação de Lukács sobre o "estilo happy end" do realismo socialista, imposto pelo esquematismo dogmático do stalinismo e correlato ao que Sartre considerou como a atitude conceptualizante das "opiniōes pré-concebidas da planificação" (1973: 127).

Exemplar para Graciliano Ramos é a ressalva de Lukács após a advertência de que a aplicação do marxismo (ou a filiação partidária do autor...) nāo significa nada para a literatura daí produzida: "para o escritor, efetivamente, nenhuma teoria, nenhum saber, tem outra função que nāo seja ajudá-lo a descobrir uma maneira mais profunda de refletir o real, no próprio plano da arte. Trata-se, neste caso, de uma relação indireta, de ordem dialética" (1969: 174,141). Graciliano nāo está para a literatura como Stalin para a administraçāo politica. A homologia, que o tempo sugere, desfaz-se quando vemos a humanidade dialética do primeiro fazer interagir arte e realidade na representaçāo estética, e o segundo, mecânico, prensar moldes teóricos grosseiros sobre a história, limpando as rebarbas humanas de seu modelo autoritário. Os termos mediadores que conduzem a relação figurada podem ser a "orto-doxia", a "organizaçāo", a "uniformidade", o "racionalismo de planejamento". Esquematismo, praticismo, empirismo, naturalismo e positivismo são os componentes da máquina por onde se enrosca no seu tempo a literatura de Graciliano Ramos. Mas sāo também a esteira do século que o autor utiliza para se desenroscar de positivismo, naturalismo, empirismo, praticismo e esquematismo.

Se marxismo e positivismo sāo faces da mesma moeda do tempo, marxismo e positivismo tornam-se equivalentes da relação marxismo - stalinismo. Ao dissertar sobre a concepção dialética da história, sua difusão didática e sua prática popular, Gramsci dá atenção especial ao "aroma" ideológico imediato da "filosofia da praxis": "uma forma de religião e de excitante (mas da natureza dos narcóticos), necessária e justificada historicamente graças ao caráter 'subalterno' de determinados estratos sociais". 
FALLEIROS, Marcos Falchero. Onde canta o sabiá.

O "aroma" do marxismo a que Gramsci se refere implica determinismo, fatalismo, mecanicismo. Naquilo que se refere ao aprendizado e à iniciação dos "subalternos", considera-o estrategicamente útil para quando falta iniciativa das lutas e para as derrotas: ai, "o determinismo mecânico transforma-se em uma formidável força de resistência moral, de coesão, de perseverança paciente e obstinada. 'Eu descreio momentaneamente, mas a força das coisas trabalha por mim a longo prazo, etc. ' A vontade real se disfarça em um ato de fé numa certa racionalidade da história, em uma forma empírica e primitiva de finalismo apaixonado, que surge como um substituto da predestinaçāo, da providência, etc. , das religiōes confessionais" (1986: 23).

O modo racionalizado dessa nova "religião" revela sua forte significação na palavra "mecânico". A generosidade do pensamento de um Gramsci encarcerado por Mussolini, antes de restringir o papel dessa nova fé mecanicista, caracteriza-a como "aroma" do marxismo: é a mais clara indicação de que a teoria tirada das máquinas não só traz o seu cheiro como também corre o risco de ser novamente sugada por elas.

Atrås da razão perdida, razão-frankenstein. Adorno e Horkheimer, como se fossem locutores apressados de um documentário sinistro, diagnosticam o seu tempo vendo no positivismo a "escória da Ilustração". Tal quadro pode ser particularmente evidenciado pelo momento em que os filósofos passam por Kant em Hollywood e observam a ambigüidade da razão: pura e empirica, em seu conflito contém a promessa da "solidariedade consciente do todo", mas, ao mesmo tempo, ela é o "pensamento calculador" da "autoconservaçāo": "A verdadeira natureza do esquematismo, que consiste em harmonizar exteriormente o universal e o particular, o conceito e a instância singular, acaba por se revelar na ciência atual como o interesse da sociedade industrial. O ser é intuido sob o aspecto da manipulaçāo e da administraçāo. Tudo, inclusive o individuo humano, para não falar do animal, converte-se num processo reiterável e 
substituivel, mero exemplo para os modelos conceituais do sistema" (1985: 82).

Esse é o contexto de Graciliano Ramos. Relacionado dialeticamente a ele, o categórico impressionável estereotipa no jogo entre realidade impressionante e resposta categórica, as peças fixas da conceptualização. Mas sua independência partidária organiza o real a seu modo, cuja solitude implica a fonte única de uma subjetividade emotiva: é de um sentimento do mundo que vêm seus valores esquematicamente racionalizados. Sua lógica de construtor nasce de um sentimento de justiça enraizado na sabedoria infantil solitária, aprendida na carne.

Como a tragédia, mais próxima da filosofia que do relato (Aristóteles, 1973: 451), a retórica do seco, detida em crispação no cruzamento da direção interna da literatura e da direçāo externa do mundo (Frye, 1979: 78), recolhe, com tom "asseverativo", a ficção e a confissão na direção interna da arte: re-presentação: "no âmago da sua arte há um desejo intenso de testemunhar sobre o homem"- diz Antonio Candido. A densidade reflexiva do escritor desenraizado do mundo atravessa o percurso de seu olhar desentendido, estrangeiro e exilado, indo da "necessidade de inventar" à "necessidade de depor" - nos termos como Antonio Candido explica a passagem da ficção à confissão, dos romances à última fase, a das memórias: "a transição não se apresenta como ruptura, mas como conseqüência natural, sendo que nos dois planos a sua arte conseguiu transmitir visões igualmente válidas da vida e do mundo" (1969: 18).

Visto à distância, entretanto, o conjunto mostra que mais do que a expressão de necessidade intima e psicológica, há nesse percurso o caráter sistemático da obra, que dirige esse caminho com consciência silenciosa - não programática. Também no retalhamento da obra em unidades, o autor se caracteriza por aquilo que Deleuze aponta como a atitude oposta de Proust. Sob o titulo "Antilogos", com o qual qualifica este, o filósofo diz: "No logos há um aspecto, por mais oculto que esteja, pelo qual a Inteligência vem sempre antes, pelo qual o todo já se encontra presente e a lei já é conhecida antes daqui- 
lo a que se vai aplicá-la: passe de mágica dialético, em que nada mais se faz do que reencontrar o que já estava dado de antemão e de onde só se tiram as coisas que ai tinham sido colocadas" (1987: 104).

É comum encontrarmos em referèncias à sua obra, e nela própria, o olhar desgostoso do autor apontando aspectos rebarbativos em sua criaçāo. Otto Maria Carpeaux diz em "Visāo de Graciliano Ramos": "Quer eliminar tudo". E: "Seria capaz de eliminar páginas inteiras, capitulos inteiros, eliminar os seus romances inteiros, eliminar o próprio mundo". Mas é necessário abrandar o comentário hiperbólico de Carpeaux, que acaba atribuindo ao escritor a intenção de restar só no puro "lirismo", "amusical", "estático" (1988: 193), para que Graciliano exista um pouco além desse cogito lírico. Poderemos, assim, considerar a obra ficcional do sistemático, passada a limpo, resumida essencialmente no seguinte: o burguês em São Bernardo, o pequeno-burguês em Angústia, e o proletariado em Vidas secas, esgotando o ciclo ficcional com o mapeamento cristalizado do homemclasse e de sua condição na história.

Marxista, Graciliano ao invés de pedir a regurgitaçāo do real, procura enquadrá-lo na grade tensa da luta de classes, e, autor-ator (Pinto,1962), no espelho humano de si mesmo perscrutar o interior desses viventes exemplares. Fica longe, portanto, no "todo" de que parte angustiadamente em busca de saida histórica, daquelas abstraçōes de que falava Roberto Schwarz, "da faixa da extrema esquerda para a qual é indispensável desconhecer a realidade ('isto é grave, companheiro, é empirismo')" e que falavam em "Proletariado", em "Revoluçāo", termos "infinitamente repetidos mas vazios de trabalhadores reais e de movimento social" (1987: 84).

Consagrado o romancista, depois do batismo de fogo de Angústia, "autobiografia" romanceada, realidade incorporada com fantasia esquemática, desejo e premoniçāo, realiza-se a passagem fluida para a direção externa do real em Infância, a "ponte" vinda depois de Vidas secas, "ponte", retorno à direçāo interna, em ir e vir, na forma, que revela o estilo, e no conteúdo, que deixa à tona o fundo da psiquê 
dessa escrita, narrando suas origens sem mencionar seus desdobramentos futuros: mapeamento daquele presente: as razōes da obra enraizadas na infância, a gênese da autoria. É um movimento especular infinito no ir e vir entre forma e conteúdo, ali na unidade do livro, que assimila autor-obra-história: evento.

A leitura de Hermenegildo Bastos, que interpreta Memórias do cárcere como expressão cumulativa de um conjunto de obra orgânico, endossa o conceito de autoria e evento e aprofunda o sentido de sua configuraçāo estética: "Se personagens e situaçōes dos outros livros ressurgem nas Memórias do cárcere, isso não deve desacreditar a autenticidade do relato. $O$ ressurgimento de personagens ficticios na pele de personagens reais indica que o universo temático e de interesse humano do autor permanece o mesmo e que, no momento de passar a vida a limpo, esse universo, que tem fundo autobiográfico, mostra-se em sua inteireza" (1998: 87).

Ao abordar o caminho histórico da obra, Valentim Facioli observa em "Um homem bruto da terra": "A direção desse movimento é o sentido de uma 'atualização', que salta qualitativamente de um exercício inicial de romance de costumes interioranos, na base das convenções romanescas do Realismo que vem do século passado, como Caetés, que significa pouco para a cultura letrada do país, e chega às Memórias do cárcere" (1987: 98). A "ponte" conduz da origem da autoria em Infância ao seu tempo final em Memórias do cárcere, onde a obra do Nordeste - reduto fora do qual ela se esvazia como na sementeira estiolada dos contos - agora desce prisioneira pelo mar da história para a capital do Brasil, um dos setores onde o movimento comunista internacional é encarcerado pelo fascismo vitorioso. Nesse percurso entre grades e porões, vigorosamente concreto, ela carnaliza na direção interna da literatura o percurso do regional ao universal, tanto quanto manifesta exemplarmente, na literatura e na história, o vínculo dialético, necessário e insofismável, entre história e literatura. Ao mesmo tempo, por terra, vêm descendo, inocentes disso tudo, as almas penadas que ele perscruta como um oráculo, em busca 
FALLEIROS, Marcos Falchero. Onde canta o sabiá.

desolada e esperançosa de possibilidades revolucionárias: Sinha Vitória, Fabiano, os dois meninos.

Sāo Bernardo, Angústia, Vidas secas, Infância, Memórias do cárcere, postas em destaque, no modo reduzido bem ao gosto de Graciliano, mostram que o mosaico, em seu trabalho de dotação de sentido, vai muito além da unidade fechada que faz de "cada uma das obras de Graciliano Ramos um tipo diferente de romance", como observou Aurélio Buarque de Hollanda (apud Candido, 1971: 113). Nessa unificação orgânica do todo, em cada uma de suas especificidades crispadas sob o principio econômico e utilitário de "o resto é bagaço" - para usar a expressão chave de Paulo Honório - não somente palavras, frases, capitulos, enredos são pinçados do resto-real e pairam acima dele em sinopse. O próprio desfilar da obra encerra a totalidade na configuraçāo do estilo contiguo e recortado, das cenas entre lacunas, das palavras entre lacunas, em cujos vazios a presença escura da autoria ordena elos de contigüidade, lacunas que interrompem a fluidez do contexto, para mantê-lo teso de coerência: é a figura da grade peneirando peças contra a luz do real.

\section{A empiria impossível}

Essa tradição critica formada pela observação de Aurélio Buarque de Hollanda a respeito da independência de cada romance levou Alfredo Bosi à idéia de "série", que a obra de Graciliano sugere com a figura da grade, contra a tendência ao "ciclo" do regionalismo de 30. É o que Flora Süssekind assimila, citando esta passagem da História concisa da Literatura Brasileira: "Escrevendo sob o signo dialético por excelência do conflito, Graciliano não compôs um ciclo, um todo fechado sobre um ou outro pólo da existência (eu / mundo), mas uma série de romances cuja descontinuidade é sintoma de um espirito pronto à indagação, à fratura, ao problema". Perde-se entretanto com essa avaliação o caráter conceptualizante que busca com- 
por uma interpretaçāo orgânica do todo histórico, o que não anula a pertinência da idéia de série para qualificar a obra. Diz Flora Süssekind: "Quando explicita em seus romances o trabalho com a linguagem, Graciliano joga por terra a obsessão fotográfica e documental dominante no neonaturalismo de Trinta. Dominante tanto num Jorge Amado quanto num José Lins do Rego", "Via Paulo Honório, Graciliano explicita o trabalho com a linguagem que se acha envolvido na produçāo romanesca. Desmente a obsessão especular do naturalismo. Paulo Honório se mostra como narrador e ao seu romance como construçāo, produção e não simplesmente transparência por meio da qual se enxergaria a realidade" (1984: 170).

Ao articular a polaridade entre um neonaturalismo de Jorge Amado, de José Lins do Rego e um construtivismo de Graciliano Ramos, Flora Süssekind perde a unidade de comportamento que agrupava o conjunto da literatura de Trinta. $O$ anti-bacharelismo, a idéia do anti-literário, o rompimento com o ornamental são plataformas comuns a todos, tanto no "minimo de literatura" mencionado pela autora em referência a Jorge Amado, quanto na intenção de José Lins do Rego de fazer uma obra com o minimo possivel de "palavras", "disfarces retóricos" e "imagens poéticas". Não deixa de ser pertinente a diferenciaçāo desses pólos, que empurra para o outro lado a "construçāo" em Graciliano Ramos, pólo caracterizado pela ausência de um descritivismo profuso e naturalista da "cor local". Mas talvez o que tenhamos ai, apesar de unidos pelos mesmos propósitos estéticos do periodo, seja a dualidade universal entre o fluido e a construtivo que Merleau-Ponty encontra exemplificada no surrealismo de Breton e no apuro formal de Valéry, caminhos opostos que se unem dentro de uma concepção para a qual a essência da linguagem é "ela não se apagar diante do que nos comunica, nela o sentido reclamar as próprias palavras, e não outras, que serviram para comunicá-lo. que não podemos resumir uma obra, mas que para a reencontrar é preciso relê-la, que aqui a idéia é produzida pelas palavras", "em razão de relaçōes de sentido mais carnais" (1962: 356). 
FALLEIROS, Marcos Falchero. Onde canta o sabiá.

A plataforma estética sob a legenda de "o resto é bagaço", com a qual na verdade Graciliano Ramos expressa as propostas de seu tempo, parece muito mais se opor à tradiçāo literária do século XIX, oposiçāo ao "cavalheirismo ornamental" que já pode ser atribuída a Machado de Assis, como podemos deduzir de suas crônicas em $L i$ nhas tortas. Em "Os amigos de Machado de Assis" lemos sobre a impopularidade desse escritor: "No interior do pais, nas mais afastadas populaçōes, senhoras idosas tremem, umedecem os óculos gaguejando as histórias de Moço loiro e da Escrava Isaura, emprestam às netas brochuras do romantismo, conservadas miraculosamente. Alencar circula e deve-se a ele haver por ali tanta Iracema, tanto Moacir. Não é razoável, porém, esperarmos que o leitor comum, que se agita com excessos literários de meado do século XIX, entenda e sinta Machado de Assis, homem frio, medido, explorador de consciências". Na crônica seguinte, a respeito da mitificaçāo do autor, Graciliano diz: "Tanto se repetiu o nome do velho presidente da Academia, com a afirmação de que ele influia demais na produçāo de hoje, que o homem se tornou odioso. Se um sujeito admitia a concordância e não trocava o lugar das palavras, o jornal dizia: 'Bem. Isto é Machado de Assis'. Se o camarada evitava o chavão e nāo amarrava três adjetivos em cada substantivo, a explicação impunha-se: 'Muito seco, duro. Esqueleto. Machado de Assis'. Faltavam num livro cinqüenta páginas de paisagem? 'Claro. Esse homem aprendeu isso com Machado de Assis. É a história da casa sem quintal"' (1980: 107, 109110).

De fato é com essa tradição do século XIX, o grande lastro doméstico e escolar da cultura brasileira da época, que a obra de Graciliano dialoga. Sobre sua iniciação na literatura, ele conta em Infância: "Jerônimo abriu a estante, entregou-me sorrindo O guarani, convidou-me a voltar, franqueou-me as coleçōes todas.

Retirei-me enlevado, vesti em papel de embrulho a percalina vermelha, entretive-me com D. Antonio de Mariz, Cecilia, Peri, fidalgos, aventureiros, o Paquequer. Certas expressões me recordaram a 
seleta e a linguagem de meu pai em lances de entusiasmo. Vi o retrato de José de Alencar, barbado, semelhante ao Barāo de Macaúbas, e achei notável usarem os dois uma prosa fofa" (1981: 222).

Mas a racionalidade a que a literatura de Graciliano Ramos dá expressão não se limita à secura do viés econômico contra a "prosa fofa" do Brasil pitoresco de Alencar. Mais do que isso, tal racionalidade atinge a dimensão conceptualizante direcionada para um mapeamento estrutural do pais. É o periodo de 30, propicio à "sociologia", ao "materialismo", dimensão que o tempo romântico da Independência nāo podia ver. Dai o reconhecimento do país, que Alencar programaticamente conduz, realizar-se pelo percorrimento empirico, entregue ao processo constatativo e, no caso, ambientado pela "visão conciliadora" de um pensamento conservador em busca de provas para seu nacionalismo ufanista, em fase de auto-afirmaçāo.

Trata-se pois de uma entrega ao tateio da particularidade cujo parti pris garante o encontro do nacional a qualquer hora de sua história e em qualquer lugar de seu território. Diz Afrânio Coutinho sobre a polêmica de Alencar com A confederaçāo dos tamoios, de Gonçalves de Magalhães, quando o primeiro recusa o gênero épico como impróprio para o contexto brasileiro: "Para Alencar, o poema brasileiro teria de refletir a luz e a beleza do pais, as cores, a forma graciosa das suas flores, 'a harmonia das auras da tarde', teria fatalmente de ser como 'essa tela brilhante de uma natureza virgem e tão cheia de poesia'. Confessa-se um leitor do 'livro da natureza', e por isso é 'dificil em matéria de beleza plástica, e mesmo de metrificação', pois 'o ouvido habituado ao frouxo roçar das árvores, no murmurejo das ondas, aos ciclos das brisas, a essas folhas de rosa de harmonia, nāo pode sofrer certos versos com a mesma indolência do ouvido acostumado ao rodar das seges e ao burburinho das ruas' " (1968: 100).

A tarefa desse tateio encontra, pois, dificuldades próprias de um garimpo, envolvendo os constrangimentos e censuras que enfrenta provindos da configuraçāo artificial sob colonizaçāo à qual foi submetida sua naturalidade. É o que podemos ver em tom polêmico 
no prefácio a Sonhos d'ouro. A complexidade ideológica do seu tempo já dá nota pelo modo ingênuo e afetado de Alencar. Tuteando seu "livrinho", conversa paternalista com ele, advertindo-o sobre o que vai enfrentar, benevolente desde o título "Bênçāo paterna", sem deixar de ser ressentidamente irônico com seus opositores: "Aos que tomam ao sério estas futilidades de patriotismo e professam a nacionalidade como uma religião, a esses hás de murmurar baixinho ao ouvido, que te não escutem praguentos, estas reflexões: 'A literatura nacional que outra coisa é senão a alma da pátria, que transmigrou para este solo virgem com uma raça ilustre, aqui impregnou-se da seiva americana desta terra que lhe serviu de regaço; e cada dia se enriquece ao contato de outros povos e ao influxo da civilização?' ".

O sentimento das "idéias fora de lugar" è o que obseda o tempo. Vemos assim um romance tolo, de consistência estética frágil, encapado por polêmicas altissonantes: depois da "Bênção paterna" do prefácio, José de Alencar retorna em posfácio para defender verossimilhanças nacionais do enredo, contra acusaçōes da critica, uma delas paradoxalmente sobre a aristocracia postiça da protagonista: "Não há capricho no Brasil?", "Estará a aristocracia de Guida no passear na Tijuca em cavalo do Cabo? Em trazer roupāo de cachemira e luvas peau de Suède? Em ter uma governanta e criado estrangeiro para acompanhá-la?", "Creio que a sociedade fluminense em peso protestaria contra semelhante apoucamento de nossa corte. Não é preciso ser filha de capitalista para ter semelhante tratamento": eis os termos do debate cômico e provinciano.

O amálgama do externo com o interno è o seu busilis. Trata-se de uma tradiçāo polêmica já formada desde os primórdios do periodo, como indica Afrânio Coutinho: "No inicio do romantismo, travou-se no Brasil uma querela de antigos e modernos entre a norma de inspiraçāo na mitologia clássica e a da americanidade na criação poética. Donde partiria a inspiraçāo do artista: da natureza ambiente, ou da educaçāo, cultura e imitação?" (1968: 67). Voltando à "Bênção paterna" que batizou Sonhos d'ouro, lemos: "A grande inteligência de Ale- 
xandre Herculano nos profetizara uma nacionalidade original, transfusão de duas naturezas, a lusa e a americana, o sangue e a luz. Mas os ditadores não o consentem; que se há de fazer? Resignemo-nos. Este grande império, a quem a Providència rasga infindos horizontes, é uma nação oca; não tem poesia nativa, nem perfume seu; há de contentar-se com a manjerona, apesar de ali estarem recendendo na balsa a baunilha, o cacto e o sassafrás": uma discussão que se estende do olfato ao sotaque, como indica o final do prefácio estabelecendo padröes lingüisticos entre o "chupar", de conotação mais bruta, e o refinado "sorver": "Estando provado pelas mais sábias e profundas investigaçōes começadas por Jacob Grimm, e ultimamente desenvolvidas por Max Müller, a respeito da apofonia, que a transformaçāo mecânica das linguas se opera pela modificação dos órgãos da fala, pergunto eu, e não se riem, que é mui séria a questão: $O$ povo que chupa o caju, a manga, o cambucá e a jabuticaba, pode falar uma lingua com igual pronúncia e o mesmo espirito do povo que sorve o figo, a pêra, o damasco e a nêspera?" (1981: 10,158,9,12).

Em busca das raizes que fizeram florescer as inquietações das vanguardas modernistas, ainda em torno de sua pertinência em paises subdesenvolvidos e das possibilidades de uma expressão independente, Ferreira Gullar encontra o paradoxo do indianismo no paradoxo maior e incontornável de uma cultura nascida do processo da colonização, que aclimata o individualismo romântico na direção do nacionalismo, fazendo prevalecer seu conteúdo ideológico para o movimento de formaçāo de uma literatura brasileira autônoma. Porém, mais uma vez a busca de uma autenticidade do natural revertese em artificialismo: "É fato que essa imagem do indio firma-se numa abstração do bon sauvage dos utopistas do século XVIII." (1969: 23).

Vê-se portanto o periodo condenado estruturalmente à polêmica. A intenção de um tateio empírico da naturalidade se constrangia pela constatação das formas culturais importadas, cujos instrumentos obrigavam à sensação incômoda do artificialismo, tanto quanto, como observa Lucia Miguel Pereira, o conflito entpe tünaginação e 
FALLEIROS, Marcos Falchero. Onde canta o sabiá.

observação, que dirigiu a passagem de romantismo a realismo: "O que a geração romântica nos podia dar já dera: a consciência de emancipação literária - relativa e fraca emancipação que só nos libertara do jugo lusitano - e a certeza de que saberiamos aproveitar os nossos próprios temas. No indianismo ou no caboclismo que lhe sucedeu, o que, deliberada ou confusamente, se buscou, foi a existência do brasileiro, de um tipo humano nacional, diverso dos colonizadores: e agora que já contávamos meio século de vida independente, o expediente indianista revelava a sua artificialidade". E sobre a passagem do romantismo ao realismo, acrescenta: "Certo, a observação já concorria com a imaginação nas obras dos românticos: mas o que nelas fora um subproduto, fruto da necessidade de pôr em evidência a cor local para mostrar que existiam brasileiros, passava agora a produto principal" (1988: 34).

Devedora da categorização estranhada dos relatos de viajantes europeus sob contexto tropical, a constituiçāo do narrador de ficção na literatura brasileira, como interpreta Flora Süssekind, pode ser figurada pela sua citação de Gilda de Mello e Souza em Exercicios de leitura, a respeito da pintura brasileira e seus precursores: "Os próprios cronistas, tão atentos ao registrar os traços da cultura material dos indios, fracassam quando procuram lhes apreender os gestos. Os indios representados nas gravuras dos livros de Thévet, Léry, Hans Staden têm não só a mesma constituição fisica das personagens mitológicas das gravuras do Renascimento, como a mesma desenvoltura heróica. Se compararmos a sua maneira de empunhar o arco e a flecha com as registradas em nossos dias pelas fotografias dos etnógrafos, veremos que ela nāo deriva de uma observaçāo fiel da realidade. Supondo reproduzir o que viam, transpunham na verdade para a selva brasileira certos esquemas tradicionais que lhes pareciam um 'ponto de partida bem mais verossimil'" (1990: 294).

Sabemos o caminho dessa condição na gênese de nosso "tarzā", como mostram os comentários irônicos de Raimundo Magalhães Júnior a respeito da linhagem literária de $O$ guarani: "Na verdade, 
Peri é uma figura tāo irreal como os seres mitológicos, a tal ponto que, a uma de suas intervenções, o autor diz que 'o selvagem surgira como o gênio benfazejo das florestas do Brasil', nāo sabendo Dom Antônio de Mariz o que mais admirar, se a força e o heroísmo com que salvara sua filha, se o milagre de agilidade com que se livrara a si próprio da morte", observando mais à frente: "As proezas praticadas pelo Tarzã, branco que se converte em selvagem, nos romances populares de Edgard Rice Bourroughs, nāo passam de simples paródias das façanhas de Peri. Este já se movimentava sobre as copas das árvores e utilizava os cipós com a maior naturalidade", "Peri era também, a seu modo, um homem-macaco" (1977: 88-89).

Resultado patético, se lembrarmos dos projetos presumidos que argüiam $A$ confederação dos tamoios de Gonçalves de Magalhães, mas que nem por isso deixaram de passar por percepções atiladas, como a que encontra no romance uma forma literária mais adequada que a epopéia para a expressão da nacionalidade. Diz ainda Afrânio Coutinho: "Assim, propôs Alencar ao espírito literário que mergulhasse no magma nacional, na realidade histórica e social, para buscar a matéria-prima com que construiria a literatura brasileira, e isso armado de um gênero moderno, flexivel, adaptável a todas as condiçōes de vida, como o romance, bem diverso da epopéia" (1968: 102).

Mas tal percepçāo, realista quanto à propriedade dos gêneros. antecipando de maneira primária e intuitiva as grandes teorizaçōes do romance que o século XX produziria, como as de Lukács e Benjamin, nāo seria suficiente para evitar conteúdos fantasiosos da imaginaçāo e colher com a observaçāo a brasilidade que calasse as criticas, tāo proliferas num contexto todo devotado a essa prática entusiasta, muito fomentada mesmo pelo autor. Ao historiar a segunda metade do século XIX brasileiro, como periodo de significativas polêmicas culturais sob viés bacharelesco, Roberto Ventura fala sobre as restrições de Nabuco a Alencar: "A posição de Nabuco aponta para a exclusão do escravo e do indigena da vida cultural e social, por meio da aboliçāo do cativeiro e da sua eliminação como tema literário. Como 
FALLEIROS, Marcos Falchero. Onde canta o sabiá.

representante de uma etnia tida como inferior, o escravo seria uma "linha negra'que limitaria e comprometeria o pais" (1991: 41). A respeito podemos acrescentar o comentário de Afrânio Coutinho, que contrapōe a tendência "ocidentalista" de Nabuco à "brasilista" de Alencar: "Os primeiros insistem nas raizes européias de nossa cultura, no universalismo e ocidentalismo, que são o seu ponto de partida, procurando fazer delas a essência de nossa civilizaçāo. A nossa dependência à Europa reflete-se no interesse da Metrópole lusitana e da classe branca dominante, interesse que prevalece na historiografia tradicional luso-brasileira. Do outro lado, os nativistas, sem voltar as costas à Europa e à herança cultural greco-romano-cristā, encaram o Brasil como algo novo, um complexo cultural e racial diferente" (1991: 112).

Falsas questōes e articulaçōes ideológicas arrevesadas já no conteúdo não podem dar conta de seu vinculo com a opção pela forma do romance, quando então esta é abstraida das razões históricas de sua gênese e tomada como fôrma sobre a qual se despejaria a brasilidade - o que resultaria em novas inquietações e polêmicas. Roberto Schwarz demonstra a mútua relação entre enredo e história que o instrumental teórico de Alencar era incapaz de ver. Em Ao vencedor as batatas, no capitulo "A importação do romance e suas contradiçōes em Alencar", o critico retoma "O narrador" de Walter Benjamin, conduzindo-o para o exame da situação especifica da condição colonial, quando o contexto atrasado desta, propicio às caracteristicas da narrativa oral apontadas por Benjamin, entra em confluência com a forma importada do romance. Revela-se ai o paradoxo em que a defasagem de maturação histórica causada pela importaçāo do romance no Brasil, relativamente à simplicidade da narrativa pré-capitalista e à organicidade do movimento da história que a ultrapassou com o romance na Europa, faz de suas soluçōes ingênuas e desajustadas, como na obra de Alencar, algo mais complexo e acumulado que no processo de origem, a ponto de a exaltação romântica da natureza passar a ufanismo de cartão postal: "Neste sentido vejam-se 
também O guarani e a bela descrição inicial de $O$ tronco do ipê. Guardadas as proporções, é o ritmo da grande meditação romântica, em que à custa de silêncio e intensidade mental a complexidade do mundo é apreendida e retida, para recompor-se - em minutos de plenitude e clareza exaltadas - segundo a ordem fluente, não-mutilada, da imaginaçāo" - "Ai uma diferença importante: a natureza alencarina tem muito disso, é efetivamente repassada de nostalgia, mas por instantes lhe acontece de ser a paisagem brasileira e mais nada. Onde os românticos, polemizando contra o seu tempo, imaginariamente repristinavam percepçāo e natureza, Alencar contribui para a glória de seu pais, cantando-lhe a paisagem e ensinando os patricios a vêla. O sortilégio romântico serve-lhe de fato para valorizar a sua terra, e não para redescobri-la contra os contemporâneos menos sensiveis. Assim, a exaltação romântica da natureza veio a perder entre nós a sua força negativa, e acabou fixando o padrāo de nosso patriotismo em matéria de paisagem" (1977: 58).

A existência de romances no Brasil antes de terem existido romancistas brasileiros é o núcleo de ressonâncias complexas, que atingem em âmbito amplo a condição colonial do pais e o estatuto de sua formação cultural, cuja sintese sob forma de metáfora aparece na desconfortável expressão "idéias fora de lugar". Para deixar logo de lado a polêmica que essa expressāo causou no momento da publicação de Ao vencedor as batatas no final dos anos 70, e que ainda perdura, podemos lembrar que o autor nāo a professa como um diagnóstico pelo qual teoricamente se responsabilize, mas que a utiliza como forma de indicar a auto-imagem do pais. Apesar do alcance genérico e ainda hoje permanente, tal como o autor a menciona em outros ensaios, no contexto desse seu trabalho de crítica literária, a expressão é situada no século XIX, particularmente na contradição experimentada pelos estratos intelectualizados, que conviviam com a simultaneidade disparatada da ideologia liberal dominante e da aberraçāo escravocrata, ou, em outros termos, entre a dependência de origem que disseminava em solo brasileiro as idéias européias sobre 
FALLEIROS, Marcos Falchero. Onde canta o sabiá.

trabalho livre como valor humanista e a presença cotidiana do escravo a desmenti-las.

Do mesmo modo, combinar matéria local ao molde europeu do romance foi um desafio para os escritores brasileiros. A Senhora, Aurélia, de Alencar, tem em seus arrufos grandiloqüentes algo de disparatado, de descabido e de contraditório. Comprando o casamento por meio de negociação escusa, a menina pobretona enriquecida por herança, que então se vinga do amado que a abandonara por um dote mais atraente, acaba por encenar uma afetação de principios liberais e humanistas em contraste cômico com o movimento circunstancial do romance. Assim, discurso dramático e ressentido aparece cercado de personagens menores, cuja configuraçāo lembra Memórias de um sargento de milicias. A contradição dos "principios" frente a uma sociedade escravista faz o fundo desse sentimento de desencontro, que levava Alencar a se desculpar da pequenez de seus romances, argumentando estar condicionado ao "tamanho fluminense".

Em Dialética da malandragem, Antonio Candido encontra "no tempo do rei" de Memórias de um sargento de milicias, uma "civilização fora de hora", paralela ao desvendamento posterior que Roberto Schwarz retomou com o diagnóstico das "idéias fora de lugar". O sentimento de desajuste em relação aos centros europeus conforma a idéia de imaturidade civilizacional, que, ao invés significar bisonhice, pode cevar contra a modernizaçāo conservadora o otimismo de um tempo em allegro vivace, indicado no romance como propício ao advento de um "mundo aberto".

Ao invés de indios cantando ópera, formigas no piquenique empertigado ou crianças buliçosas sobre a geometria das carteiras escolares podem ser a imagem adequada ao viço dessa dialética de ordem e desordem que plasmou, entre o romance europeu e o contode-fadas, "o realismo brandamente fabuloso" de uma forma tipicamente brasileira de romance ingênuo. No primitivismo "sem cálculo" de sua condição atrasada, a ingenuidade perverso-polimorfa do "mundo sem culpa", pré-burguês, aponta perspectivas favoráveis ao mo- 
mento pós-burguês, como também propunha o "ufanismo critico" de Oswald de Andrade.

Antonio Candido demonstra que o estilo de bonomia de Memórias de um sargento de milicias se faz desvinculado da ideologia das classes dominantes de seu tempo. A partir de uma neutralidade moral correspondente a uma neutralidade social, a obra torna-se exemplo da tendência a desarmar ideologias com a irreverência popularesca, que, articulada a uma tolerância corrosiva "muito brasileira", manifesta-se em nosso literatura revelando a intenção de devastar pela piada os valores postiços e artificializados que ameacem cristalizar a fluide $z$ fecunda que é caracteristica de nosso universo cultural.

Ao qualificar desse modo seu contraste com a literatura do tempo, Antonio Candido encontra uma vertente da literatura brasileira, onde estão Gregório de Matos, Macunaima, Serafim Ponte-Grande, à qual filia Memórias de um sargento de milicias. Pelo contraste diacrônico e pela filiação sincrônica da obra, acaba por abrir a possibilidade de uma partição de procedimentos estéticos que enformaria nossa literatura através da opção entre o cristalizado e o fluido.

No período histórico de Manuel Antonio de Almeida, o romantismo deixava a vertente cristalizada aos projetos da elite: "Uma sociedade jovem, que procura disciplinar a irregularidade da sua seiva para se equiparar às velhas sociedades que lhe servem de modelo, desenvolve normalmente certos mecanismos ideais de contensāo, que aparecem em todos os setores". Em relação à literatura, esse aspecto aparece no gosto acentuado pelos simbolos repressivos: "É o que vemos, por exemplo, no sentimento de conspurcação do amor, tão freqüente nos ultra-românticos. É o que vemos em Peri, que se coíbe até negar as aspirações que poderiam realizá-lo como ser autônomo, numa renúncia que lhe permite construir em compensaçāo um ser alienado, automático, identificado aos padrões ideais da colonizaçāo".

Sem entrar na consideração de que esse artificialismo automático também exala ingenuidade, como o da construção de Peri, Antonio Candido contrapōe a liberdade "quase feèrica" de Manuel Antonio de 
FALLEIROS, Marcos Falchero. Onde canta o sabiá.

Almeida à literatura recalcada e contida de José de Alencar: "Mesmo em livro tão voluntariamente crítico e social quanto Senhora, o estilo de Alencar acaba fechando a porta ao senso de realidade, porque tende à linguagem convencional de um grupo restrito, comprometido com uma certa visāo de mundo" (1970: 86-88).

Entretanto, se lembrarmos que as projeçōes da vertente cristalizada podem não estar na māo das elites, veremos que a distinção ideológica entre esta e a da formalização fluida pode se atualizar de modo relativo, assumindo, uma ou outra, contornos reacionários ou progressistas. Para provar essa relatividade, a obra severa de Graciliano Ramos é suficiente, na medida em que, neste caso, um mapeamento marxista das condiçōes históricas brasileiras, calcado na visão regional que o autor universaliza, é o que dirige, no estilo seco e na temática que se esgota nas classes sociais, a articulação de seus romances: hirta e cristalizada.

\begin{abstract}
José de Alencar and Graciliano Ramos present different conceptions of Brazil. Jose de Alencar follows up the impossible empiricism and Graciliano Ramos sees the country replacing the marxism.
\end{abstract}

KEYWORDS: José de Alencar; Graciliano Ramos; colonialism; marxism; brazilian forms.

\title{
Bibliografia
}

ADORNO, T. W., HORKHEIMER, M. (1985) Dialética do esclarecimento. Rio de Janeiro: Zahar.

ALENCAR, J. de (1981) Sonhos d'ouro. São Paulo: Ȧtica. (Bom Livro). ARISTÓTELES (1973) Poética. São Paulo: Abril Cultural. (Os Pensadores). BASTOS, H. (1998) Memórias do cárcere, literatura e testemunho. Brasilia: Editora UnB. 
BOSI, A. (org.) (1987) Cultura brasileira. Temas e situaçōes. Sāo Paulo: Ática (Fundamentos, 18).

CANDIDO, A. Ficção e confissão (prefảcio). In: RAMOS, G. (1969) São Bernardo. Sāo Paulo: Martins.

- (1970) Dialètica da malandragem. In: Revista do Instituto de Estudos Brasileiros, n. 8. USP.

. (1971) Tese e antítese. São Paulo: Nacional.

. (1987) A educação pela noite e outros ensaios. São Paulo: Ática.

CARPEAUX. O. M. (1988) Visāo de Graciliano Ramos (posfácio). In: RAMOS, G. Angústia. Sāo Paulo: Circulo do Livro.

COUTINHO, A. (1968) A tradição afortunada. Rio de Janeiro: Josė Olympio. (Documentos brasileiros, 127).

- (1968) Introduçāo à literatura no Brasil. Rio de Janeiro: Distribuidora de Livros Escolares.

COUTINHO, C. N. (1967) Literatura e humanismo. Rio de Janeiro: Paz e Terra.

DELEUZE, G. (1987) Proust e os signos. Rio de Janeiro: Forense-Universitária.

FRYE, N. (1979) Anatomia da critica. São Paulo: Cultrix.

GARBUGLIO, J. C. et alii. (1987). Graciliano Ramos. São Paulo: Ática. (Escritores Brasileiros).

GRAMSCI, A. (1986) Concepção dialética da história. Rio de Janeiro: Civilização Brasileira.

GRANGER, G.-G. A razāo. Sāo Paulo: Difusão Europèia do Livro.

GULLAR, F. (1969) Vanguarda e subdesenvolvimento. Rio de Janeiro: Civilização Brasileira.

FRANCASTEL, P. (s.d.) Arte e técnica nos séculos XIX e XX. Lisboa: Livros do Brasil.

HOLANDA, S. B. de (1984) Raizes do Brasil. Rio de Janeiro: Josẽ Olympio.

Homenagem a Graciliano Ramos (vários autores) (1943). Rio de Janeiro: Alba.

LAFETÁ, J. L. (1974) 1930: A crítica e o modernismo. São Paulo: Duas Cidades.

LEITE, D. M. (1983) O caráter nacional brasileiro. 4. ed. São Paulo: Pioneira. LUKÁCS, G. (1969) Realismo crítico hoje. Brasilia: Coordenada de Brasilia. 
FALLEIROS, Marcos Falchero. Onde canta o sabiá.

MAGALHĀES JÚNIOR, R. (1977) José de Alencar e sua época. Rio de Janeiro: Civilizaçāo Brasileira.

MARCUSE, H. (1978) Razão e revoluçāo. Rio de Janeiro: Paz e Terra.

MARX, K. (1983) O capital. Livro I, vol. II. São Paulo: Abril Cultural.

MERLEAU-PONTY, M. (1962) O homem e a adversidade. In: Sinais. Lisboa: Minotauro.

PEREIRA, L. M. (1988) Ptosa de ficçāo (de 1870 a 1920). Belo Horizonte: Itatiaia.

PINTO, R. M. (1962) Graciliano Ramos - autor e ator. Sāo Paulo: Fac. FCL de Assis.

RAMOS, G. (1981) Infância. Rio de Janeiro: Record. . (1976) Viventes das Alagoas. São Paulo: Record. . (1980) Linhas tortas. Rio de Janeiro: Record.

SARTRE, J.-P. (1973) Questōes de método. São Paulo: Abril Cultural. (Os pensadores).

SCHWARZ, R. (1977) Ao vencedor as batatas. São Paulo: Duas Cidades. (1987) Que horas são? São Paulo: Companhia das Letras.

SÜSSEKIND, F. (1984) Tal Brasil, qual romance? Rio de Janeiro: Achiamé. (1990) O Brasil não é longe daqui. O narrador, a viagem. São Paulo: Companhia das Letras.

VENTURA, R. (1991) Estilo tropical. Sāo Paulo: Companhia das Letras. 